\title{
Does Human Capital Theory Account For Individual Higher Education Choice?
}

\author{
Alex van der Merwe, Durban University of Technology, South Africa
}

\begin{abstract}
South African higher education policy evidently assumes a human capital interpretation of the value of higher education. However, not much local evidence has been provided to support the human capital view that individuals enroll in higher education primarily on the basis of future earnings they expect to flow from such investments. This paper suggests that one reason for this circumstance is that neoclassical economic epistemology, human capital theory's philosophical paradigm, cannot deal comfortably in the currency of expectations. The paper argues that individual choice can be understood only on the variable ground of human expectations, perceptions and beliefs. Such terrain is, however, not ideally suited to neoclassical economic analysis, so traditional human capital theory relies on improbable assumptions about human behaviour to model educational choice. The discussion proposes that it is not necessary to employ a neoclassical analytical framework to demonstrate that individuals' enrolment decisions may be sensitive to their anticipated returns to higher education investments. This case study, within a qualitative research design and using principal components analysis of a purposive sample of Durban University of Technology first year students' attitudes and perceptions relating to higher education, sought to establish whether their expected returns to higher education investments are significantly associated with their enrolment choices. Using binomial logistic regression analysis, respondents' anticipated private rates of return were shown to be a significant consideration in respect of their higher education choices. This finding, the product of qualitative analysis, affirms the human capital theory proposition that individuals regard higher education as an investment, that is, as a risk versus return prospect.
\end{abstract}

Keywords: higher education enrolment, higher education choice, expected earnings, expected returns, higher education investment, human capital theory.

\section{INTRODUCTION}

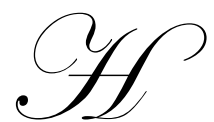

uman capital theory posits that individuals treat the commodity of higher education as an investment. Implicit in this hypothesized transaction, but also explicitly proposed by human capital theory, is the notion that formal higher education renders individuals more productive, an outcome that is supposedly recognised by employers who consequently remunerate qualified personnel according to their relatively higher marginal product.

The literature abounds with studies that report a significant association between educational attainment and ex post (historical) earnings. These observations give credence to the human capital assumption that individuals pursue higher education with primarily economic intent. Significant correlations between ex post earnings and educational attainment do not, however, explain individuals' higher education choices. In fact, only the perceptions, expectations and beliefs of individuals can give meaning to their decisions. Clearly, though, the variability and unpredictability of human behaviour cannot comfortably be reconciled with the perfect knowledge and rationality that economic agents are assumed to possess in a neoclassical economic world. Perhaps this explains why relatively few studies have ventured into the realm of individuals' earnings expectations.

Human capital theorists generally harbor a robust skepticism of expected earnings data. In spite of this, or possibly because of it, the human capital thesis that expected private rate of return is a determinant of higher 
education choice is premised on the assumption that individuals are able to anticipate their future income accurately. It has been noted, though, that little evidence exists in support of the belief that those contemplating educational investments are able to predict their future income accurately (Blaug 1976, Smith and Powell 1990). This suggests that studies claiming support for human capital theory as a model of educational choice often do so gratuitously on the basis of untested assumptions (prescribed by neoclassical economic epistemology) of the behaviour of economic agents.

This paper demonstrates that it is not necessary to employ a neoclassical economic framework to demonstrate that individuals regard higher education as an investment good and that their enrolment choices are sensitive to the returns expected of this commodity. This case study, using a qualitative research design and a limited analysis of respondents' demand for Durban University of Technology (DUT) programmes, probes the strength of association between individuals' enrolment intentions and their expected returns from investments in such programmes. As such, it assesses whether human capital theory - unhitched from its neoclassical epistemology - offers, even if only partly, a plausible explanation of individual higher education choice (and hence demand for this commodity). This study is thus one of relatively few generally, and possibly the only South African one, that have employed point earnings estimates to appropriately test the degree of association between individuals' expected rates of return and their enrolment decisions.

Section 2 briefly reviews the literature while Section 3 reviews the data and variable measurement. Section 4 discusses the analysis and Section 5 offers some concluding thoughts.

\section{AN OVERVIEW OF THE LITERATURE}

\section{Higher Education Demand Generally}

A brief review of the higher education demand literature should serve to contextualize this analysis of individuals' higher education choices. One of the earliest attempts to isolate and examine the primary influences on the private demand for higher education was made by the Robbins Committee in the United Kingdom in 1963 (Menon, 1998). It found that significant explanatory variables of educational demand were family background and economic and employment prospects associated with different educational levels and institutional variables associated with the provision of primary and secondary education.

Much contemporary education policy is in fact underpinned, either explicitly or implicitly, by human capital theory. Early contributors to this school of thought include scholars such as Fields (1974) who noted that, notwithstanding the economic and social benefits of higher education - of which only some may be measurable that accrue to society, the primary factor motivating citizens to demand education is the enhancement of their own personal economic and social status. He proposed that the demand for a given level of education may therefore be presumed to depend on the size of the expected private return to that level of schooling. Fields also included in his model, as determinants of educational demand, the non-pecuniary ("psychic") benefits of being an educated person in relation to the non-pecuniary costs as well as the ability of the individual to incur the direct costs today in order to receive future benefits.

Blaug (1976), in some pioneering work on the demand for education, placed the private demand for formal schooling at the centre of the human capital research programme. He noted that the principal theoretical implication of the human capital research programme is that the demand for higher education is responsive to variations in the direct and indirect private costs of schooling and to variations in earnings associated with differences in years of schooling. In contrast to this, observed Blaug, the pre-1960 view held by economists was that demand for higher education is in fact a demand for a consumption good and thus depends on tastes, family incomes and tuition costs.

Since the emergence of human capital theory in the early 1960s, economic factors have been widely acknowledged to influence the demand for higher education (Weisbrod 1962, Shim 1990). Boateng and OforiSarpong (2002) state that demand for tertiary education is driven by the knowledge that it is necessary for obtaining employment in the formal sector where wages appear to be higher and jobs more stable. 
The economic determinants of the private demand for higher education include factors such as the expected private rate of return from the educational investment. The limited number of these studies can be divided into two groups. The first comprises those that compute individual earnings expectations on the basis of cross-sectional historical earnings of "proxy" individuals/groups (Li and Min 2001, Hung, Chung and Ho 2000). The second group of studies generate expected returns using actual expected earnings data collected by means of surveys (Williams and Gordon 1981, Psacharopoulos and Sanyal 1982, Menon 1997). Each of these groups can again historically be divided into those that interrogate the accuracy of their expected earnings data (Handa and Skolnik 1975, Psacharopoulos and Sanyal 1982) and those that do not but are content to invoke the general finding that earnings expectations data is more or less reliable (Menon 1997, Hung, Chung and Ho 2000). Other economic factors that may influence the enrolment decision include cost of tuition (Hsing and Chang 1996, Li and Min 2001), family income (Mueller and Rockerbie 2004), financial aid for students (Michael, 1999) and proximity to the educational institution (Mora, 1997).

Non-economic determinants of the private demand for education include, among others, parents' educational level (Li and Min 2001), academic aptitude (Mora, 1997) and the broad church that could be called the private consumption value of education. The consumption value of education refers to the private utility or edification that is yielded up to the quest for knowledge. In the same way, society places a premium on educated and socially responsible citizens. Menon (1998) places the determinants of higher education demand into the following categories: economic/occupational, social/familial, psychological/individual and structural/institutional.

Differing motives for demanding education have found expression in a range of models of educational demand. Human capital theory has, for instance, tended to emphasise a pure investment approach to education demand. Some have, however, broadened the scope of their education demand models to include both investment and consumption aspects.

From an economic viewpoint, employers are increasingly demanding education and training that is responsive to the needs of the economy. Global economic changes, notes Kruss (2002), have added additional impetus to demands for education to render graduates immediately employable. She sees in this development the potential danger that the focus of higher education will become the imparting of skills required in the workplace rather than the production and dissemination of knowledge. It appears that the demand for higher education is multifaceted and one would expect this fact to pose certain challenges in terms of analyzing and anticipating its dynamics.

\section{South African Higher Education Demand}

Cosser and du Toit (2002) find that learner choices with regard to entry into higher education are influenced by various factors. These include, in the spirit of human capital theory, the extent to which higher education may lead to higher income and enhanced employment prospects. They find, furthermore, that intrinsic interest in a field of study, family encouragement and support including financial support such as bursaries are also significant determinants of higher education enrolment.

At the level of enrolment demand by institution, Cosser and du Toit observe that the most important influences upon learner choice of institution include the reputations of the institution and the particular schools, faculties and departments in question. Distance from the learner's home and the availability of accommodation are also significant determinants of enrolment demand as are the appeal of superior sporting facilities and the competitiveness of tuition fees relative to other higher education institutions. Other significant determinants of study choice are the perceived usefulness of the qualification to contribute to the country's development and the opportunity to pursue a practical course of study. The most important influences on learner choice of study programme, however, include interest in the field of study and local employment prospects offered by the qualification.

It must be accepted, consequently, that the demand for higher education is bound to be influenced by policy requirements. At the level of government there appears to be an overarching expectation that the education and training system should provide meaningful access to social and economic opportunities (Ministry of Education, 
1997).Indeed, the national minister of education has stated that the country's higher education system should respond and contribute to national human resource development and research priorities (Pandor, 2005a). Education White Paper 3 (Department of Education 1997, Mseleku 2001) identifies the imperative for higher education to produce graduates with the "appropriate" skills and competencies to meet the challenges of reconstruction and development in the context of a knowledge driven and increasingly globalizing world.

Kraak (2006) observes that a defining feature of South African universities of technology (previously technikons) is that they should be employer-centred, that is, their curricula should be honed to produce skilled, competent, productive and hence employable graduates. These types of institutions clearly perceive a strong human capital element in the essential character of the demand for the training they offer. Despite the SA government's implicit concession that its view of the role of education and training carries a strong human capital theory bias there is official recognition that education and training has a wide range of other - primarily social - functions (Pandor, 2005b). These include, among others, the role of higher education in producing socially committed graduates necessary for the defense and advancement of democracy (Council on Higher Education, 2000). It has also been suggested that higher education can play an important role in promoting a critical citizenry necessary for the monitoring and evaluating of policy. It appears, however, that the strong human capital theory bias underpinning official education policy reasserts its dominance in the Council on Higher Education's position that the role of higher education is to develop greater complementarities between the economic and humanizing goals of society.

\section{METHOD}

\section{Research Design and Survey Approach}

The study, conducted within an essentially qualitative research design, was based on a purposive sample comprising 403 first year students who were registered at DUT (Pmb) for the first time in 2006. Qualitative studies characteristically construct knowledge on the strength of observable phenomena as well as descriptions of individuals' intentions, beliefs/perceptions, expectations, values and reasons. The survey sample constitutes $42 \%$ of the target population and was sufficiently representative of the first year population of local students in respect of gender proportions and mean age. It was, however, necessary to weight the sample to represent more accurately the first year student population proportions by study field.

The empirical focus of this study was to compute individual expected rates of return and then to test, using binomial logistic regression, to what extent these are associated with respondents' enrolment decisions. The study's particular interest in the relationship between expected rate of return and enrolment choice was nested in a broader general investigation, sharpened by principal components analysis, of respondents' perceptions and attitudes relating to higher education.

\section{An Overview of the Biographical Data}

The sample mean age was 20.03 years and the median age was 20 years (population mean age $=20.3$ years). The sample comprised slightly fewer males (48.8\%) which is also true of the population (48\%). Survey sample respondents were enrolled in the following programmes: Education (25.5\%), finance/accounting (15.3\%), engineering (11.5\%), tourism (11.1\%) and public relations (9.4\%), government studies $(7.9 \%)$, human resources studies (7.1\%), management studies (6.2\%) and office management and technology (5.9\%).

\section{Expected Earnings Data}

Survey respondents were invited to provide estimates of expected monthly earnings at three stages of their working lives: at the commencement of employment, after four years of work and then again at age 46. This was done for two scenarios: assuming the respondent had achieved a higher education qualification and then also assuming that the respondent had proceeded directly into the labour market with only high school credentials. In planning the research it was anticipated that most respondents would have been about 18 years old once they had graduated from high school. Thus they would have been active in the labour market for 48-49 years if they had entered the labour market directly and if retirement age is assumed to be 65 as this study does. 
All things being equal, respondents, having opted to first engage in higher education for four years, can generally look forward to a working lifespan of 44-45 years. On this basis two possible annual earnings streams (over 48 and 44 years respectively) were computed for each respondent, that is, one without the benefit of higher education and the other with. A comparison of respondents' anticipated future earnings at the commencement of employment, after four years of work and again at age 46 was found to compare favourably with actual inflation adjusted earnings data for similarly qualified individuals at similar stages of their careers (Van der Merwe 208). This finding corroborates those of other scholars that expected earnings data is more or less accurate (Webbink and Hartog 2000, Wolter and Zbinden 2002, Botelho and Pinto 2003).

The expected annual earnings in the first four years following direct labour market entry were used to proxy the opportunity cost component (foregone earnings) of the estimated economic cost of higher education. The DUT "Fees and Finance Rules For 2006" booklet was used to establish the direct cost of tuition in respect of each of the 9 major DUT programmes currently offered at the Pietermaritzburg campuses. In addition heads of department were consulted to determine the approximate cost of books for the duration of each programme. An annual residence fee of R5 950.00 was included in the estimation of the direct cost of higher education study. Although most of the programmes are three-year full time national diplomas, it is comparatively rare for students to complete their studies in the minimum time. In view of this, the average study duration in the rate of return computations was assumed to be four years.

Respondents' cost and expected lifetime earnings data were used to compute both short-cut and elaborate expected rates of return to education investments for each respondent. The short-cut rate of return is computed as follows:

$$
r=\frac{W_{H E}-W_{S}}{N\left(W_{S}+C\right)}
$$
study, is:

The elaborate computation, assuming a working life span of 44 years after four years of higher education

$$
\sum_{t=1}^{44} \frac{\left(W_{H E}-W_{S}\right)_{t}}{(1+r)^{t}}=\sum_{t=1}^{4}\left(W_{S}+C\right)_{t}(1+r)^{t}
$$

$W_{H E}$ - Mean earnings with a higher educational qualification

$W_{S} \quad$ - Mean earnings with only a secondary school qualification (e.g. matric)

C - Direct costs of higher education (tuition, fees, books etc.)

r $\quad$ - Rate of return

N $\quad$ - Years of study

Table 1 furnishes a breakdown of respondents' expected mean private rates of return to higher education investment, both by study field as well as overall. 
Table 1: Respondents' short-cut and elaborate mean expected rates of return by study field

\begin{tabular}{|l|c|c|c|}
\hline \multicolumn{1}{|c|}{ Programme } & Sample size, $\mathbf{N}$ & $\begin{array}{c}\text { Mean short cut rate of } \\
\text { return (\%) commencing } \\
\text { employment }\end{array}$ & $\begin{array}{c}\text { Mean elaborate rate of } \\
\text { return (\%) }\end{array}$ \\
\hline ND Engineering & 46 & 39.17 & 28.65 \\
\hline $\begin{array}{l}\text { ND Office Management and } \\
\text { Technology }\end{array}$ & 24 & 39.51 & 26.51 \\
\hline ND Education & 103 & 31.60 & 23.34 \\
\hline ND Tourism & 45 & 30.02 & 21.09 \\
\hline ND Management & 25 & 40.31 & 26.35 \\
\hline $\begin{array}{l}\text { ND Human Resources } \\
\text { Management }\end{array}$ & 29 & 36.49 & 24.92 \\
\hline ND Government Studies & 32 & 36.86 & 23.34 \\
\hline ND Accounting & 62 & 27 & 19.27 \\
\hline ND Public Relations & 38 & 45.09 & 24.35 \\
\hline Overall & $\mathbf{4 0 3}$ & $\mathbf{3 4 . 6 3}$ & $\mathbf{2 3 . 2 3}$ \\
\hline
\end{tabular}

\section{ANALYSIS}

This analysis of DUT first year students' higher education choice is essentially a retrospective examination of respondents' de facto decisions to enroll for, and continue in, higher education. Thus, unlike many other studies (Williams and Gordon 1981, Dominitz and Mansky 1996, Menon 1997, Menon 1998), it is a sort of audit of the thought processes that motivated respondents' fait accompli enrolment decisions as opposed to an analysis of preenrolment higher education intentions.

\section{Attitudes toward Higher Education}

Various survey statements were employed to gauge respondents' attitudes and opinions regarding different aspects of higher education. The original responses to these statements were indicated on a five-point Likert scale but were subsequently recoded into binary variables to reflect broad agreement or disagreement with the statement. In each instance, the variable responses were recoded to disadvantage, slightly, the case for higher education. The logic in this was to avoid bias in favour of higher education. The survey statements selected include:

1. I am enrolled for my first choice qualification at DUT: "not at all/applicable to a small extent/uncertain" = no $=0$, “to a medium extent/to a great extent" $=$ yes $=1$ ).

2. In my opinion the economic benefits are the most important benefits of higher education: "not at all/applicable to a small extent/uncertain" $=$ no $=0$, "to a medium extent/to a great extent" $=$ yes $=1$ ).

3. I consider higher education as an investment that will layer pay off: "not at all/applicable to a small extent/uncertain" $=$ no $=0$, "to a medium extent/to a great extent" = yes $=1$ ).

The survey questionnaire also invited respondents, among other questions, to indicate their responses to 27 statements in respect of their perceptions of, and beliefs about, higher education. The extent to which they agreed or disagreed with each statement was similarly recorded on a five-point Likert scale thus: $1=$ not at all applicable, $2=$ applicable to a small extent, $3=$ uncertain, $4=$ applicable to a medium extent and $5=$ applicable to a great extent. Principal components analysis (PCA) with varimax rotation was used to identify and extract categories of variables from the 27 statements that might impact on respondents' educational intentions. This procedure produced 11 components, a considerable reduction from the original total of 27.

The generated components were used to collapse existing statements/variables into new and fewer variables by computing a mean score for each student's responses to statements included in the relevant component. Table 2 shows each component together with its set of variables/statements and factor loadings. Statements were excluded if their factor loadings were relatively low $(<0.6)$ or made no sense. The Kaiser-Meyer-Olkin measure of sampling adequacy (0.583) was sufficiently adequate to confirm that the factor analysis would yield distinct and reliable factors. In addition Bartlett's test of sphericity was significant $(\mathrm{p}=0.000<0.001)$ confirming the existence of certain relationships between variables. 
The principal components considerably summarize and simplify, for purposes of analysis, the individual perceptions and attitudes that respondents hold in respect of aspects of higher education. Component $\mathrm{C} 1$ consists of statements that hint at the individual regard in which students hold higher education. Component $\mathrm{C} 2$ comprises statements that point to the attitude of respondents regarding immediate employment as opposed to a prior detour via a higher education career. Components C3 and C4 are constructed from statements that reflect respondents' perceptions of university of technology versus traditional university training. Component C5 reflects respondents' willingness to trade off current versus future earnings prospects once employed. Component C6 alludes to the influence of family/social background on higher education choice. Component C7 is made up of statements that imply a consumption (or at least non-economic) value of higher education while C8 proxies respondents' unemployment risk profiles. Component $\mathrm{C} 9$ is an alternative (to $\mathrm{C} 2$ ) gauge of respondents' willingness to incur the opportunity cost of a higher education and $\mathrm{C} 10$ reflects their sensitivity to its direct costs. Component $\mathrm{C} 11$ indicates the economic value respondents place on higher education.

Table 2: Principal components and their variables/statements and factor loadings

\begin{tabular}{|c|c|c|c|}
\hline Component & & Variables/statements & Loadings \\
\hline $\begin{array}{l}\mathrm{C} 1-\text { Value placed on higher } \\
\text { education in general }\end{array}$ & - & $\begin{array}{l}\text { I believe that if I continue my education I will get a better job } \\
\text { I think that people should continue their education in order to } \\
\text { improve as individuals }\end{array}$ & $\begin{array}{l}0.654 \\
0.653\end{array}$ \\
\hline $\begin{array}{l}\mathrm{C} 2 \text { - Attitude toward immediate } \\
\text { employment vs. higher education }\end{array}$ & - & $\begin{array}{l}\text { I want to get a job after high school so as to start earning money } \\
\text { immediately } \\
\text { I think a job would have been more interesting for me than } \\
\text { higher education }\end{array}$ & 0.761 \\
\hline $\begin{array}{l}\text { C3 - Attitude toward aspects of } \\
\text { university of technology training }\end{array}$ & - & $\begin{array}{l}\text { I believe that a university of technology qualification is less } \\
\text { demanding than a traditional university qualification } \\
\text { I believe that the cost of a university of technology qualification } \\
\text { is less than that of a traditional university }\end{array}$ & 0.797 \\
\hline $\begin{array}{l}\text { C4 - Perceived labour market } \\
\text { advantage of university of } \\
\text { technology training vs. } \\
\text { traditional university training }\end{array}$ & - & $\begin{array}{l}\text { I believe that an applicant with a traditional university } \\
\text { qualification will generally be offered employment before a } \\
\text { university of technology qualified candidate } \\
\text { I believe that traditional university graduates are generally better } \\
\text { paid than university of technology graduates }\end{array}$ & 0.740 \\
\hline $\begin{array}{l}\text { C5 - Attitude towards present vs. } \\
\text { future earnings prospects }\end{array}$ & - & $\begin{array}{l}\text { I prefer a job with a good starting salary but without good } \\
\text { chances of promotion. }\end{array}$ & -0.739 \\
\hline $\begin{array}{l}\text { C6 - Family influence on higher } \\
\text { education plans }\end{array}$ & - & My parents influenced my study and career plans & 0.834 \\
\hline $\begin{array}{l}\mathrm{C} 7-\text { Perceived consumption } \\
\text { value/regard for higher education }\end{array}$ & - & $\begin{array}{l}\text { I believe that higher education does not mean higher social status } \\
\text { The risk of unemployment after my studies will not change my } \\
\text { plans to get a qualification }\end{array}$ & $\begin{array}{l}0.714 \\
0.634 \\
\end{array}$ \\
\hline $\mathrm{C} 8$ - Attitude toward risk & - & $\begin{array}{l}\text { I would prefer a job where you can earn a lot of money but } \\
\text { where there is high unemployment risk }\end{array}$ & 0.635 \\
\hline $\begin{array}{l}\text { C9 - Willingness to incur } \\
\text { opportunity cost of higher } \\
\text { education }\end{array}$ & - & $\begin{array}{l}\text { I would not mind making some sacrifices in the present in order } \\
\text { to have a better life in the future }\end{array}$ & 0.670 \\
\hline $\begin{array}{l}\text { C10-Attitude toward direct cost } \\
\text { of higher education }\end{array}$ & - & Higher education is very expensive & 0.823 \\
\hline $\begin{array}{l}\text { C11 - Perceived economic value } \\
\text { of higher education }\end{array}$ & - & $\begin{array}{l}\text { I believe that even without a higher education I can get a good } \\
\text { job }\end{array}$ & -0.690 \\
\hline
\end{tabular}

A review of these principal components, subsequently entered as regressors along with other factors to test their impact on respondents' commitment to enter and continue in higher education, suggests an approximate similarity to categories of higher education demand factors reported in the literature. Allowing for some overlap, components $\mathrm{C} 8$ - $\mathrm{C} 11$ could be broadly described as economic determinants, $\mathrm{C} 6$ as a social/family determinant, $\mathrm{C} 1$ $-\mathrm{C} 2, \mathrm{C} 5$ and $\mathrm{C} 7-\mathrm{C} 8$ as psychological/individual determinants and $\mathrm{C} 3-\mathrm{C} 4$ as structural/institutional factors. 


\section{Logistic Regression Analysis - Model 1}

Two binary logistic regression models were employed to identify factors that probably influenced respondents' motivation for enrolling for, and continuing in, higher education. The following were specified as independent variables in both models: Competence (compindex), gender (genderdummy), rural vs. urban area of residence (gebiedsdummy), maternal educational (maed, multiple categories) and employment status (maemp, multiple categories), paternal educational level (paed, multiple categories) and employment status (paemp, multiple categories), expected elaborate rate of return (ERORtw), expected employment prospects (emprospect, multiple categories), study field (Studyfield, multiple categories), respondents' ranking of DUT as choice of institution to study at (Numchoice, multiple categories) and components 1-11 in Table 2. Table 3 explains the variable coding. All multiple category dummy variables were recoded into binary $(0,1)$ notation. For the sake of brevity, some variables that were not indicated as significant are not reflected in Tables 4 and 5 which detail the model coefficients.

Table 3: Variable coding

\begin{tabular}{|c|c|}
\hline $\begin{array}{l}\text { Variable and level of measurement } \\
\text { (\# - scale, * - categorical) }\end{array}$ & Coding \\
\hline Ability\# & Compindex (Percent of subjects passed in year1) \\
\hline Respondents' relative institutional ranking of DUT * & $\begin{array}{l}\text { Numchoice }(1-5) \text { i.e. first to last choice }\left(5^{\text {th }}\right) \text {, last choice }= \\
\text { excluded category. }\end{array}$ \\
\hline Study field* & $\begin{array}{l}\text { Studyfield (1-9) } 1=\text { accounting/finance, } 2=\text { human resources } \\
\text { management, } 3=\text { management, } 4=\text { government studies, } 5= \\
\text { public relations, } 6=\text { tourism, } 7=\text { education, } 8=\text { engineering, } 9 \\
=\text { office management and technology. } 9=\text { excluded category }\end{array}$ \\
\hline Rural versus urban area of residence* & Gebiedsdummy. Area $=1$ if rural, 0 if urban \\
\hline Respondents' expectations of employment once qualified $*$ & $\begin{array}{l}\text { Emprospect }(1-5) .1=\text { very hopeful, } 2=\text { reasonably hopeful, } 3 \\
=\text { averagely hopeful, } 4=\text { not too hopeful, } 5=\text { not at all hopeful. } \\
5=\text { excluded category }\end{array}$ \\
\hline Maternal education level* & $\begin{array}{l}\text { Maed }(1-6) .1=\text { no education, } 2=\text { primary education, } 3=\text { some } \\
\text { high school education, } 4=\text { matric, } 5=\text { college, } 6=\text { university. } \\
6=\text { excluded category. }\end{array}$ \\
\hline Paternal education level* & $\begin{array}{l}\text { Paed }(1-7) .1=\text { no education, } 2=\text { primary education, } 3=\text { some } \\
\text { high school education, } 4=\text { matric, } 5=\text { college, } 6=\text { university, } \\
7=\text { other. } 7=\text { excluded category. }\end{array}$ \\
\hline Maternal employment status* & $\begin{array}{l}\text { Maemp }(1-8) .1=\text { public sector/government, } 2=\text { semi-public } \\
\text { sector, } 3=\text { private sector, } 4=\text { self-employed, } 5=\text { other sector, } \\
6=\text { unemployed, } 7=\text { does not work, } 8=\text { no mother. } 8= \\
\text { excluded category. }\end{array}$ \\
\hline Paternal employment status* & $\begin{array}{l}\text { Paemp }(1-8) .1=\text { public sector/government, } 2=\text { semi-public } \\
\text { sector, } 3=\text { private sector, } 4=\text { self-employed, } 5=\text { other sector, } \\
6=\text { unemployed, } 7=\text { does not work, } 8=\text { no mother. } 8= \\
\text { excluded category. }\end{array}$ \\
\hline Gender* & Genderdummy. Male $=1$, female $=0$ \\
\hline Components C1-C11\# & See Table 2 \\
\hline Elaborate rate of return & ERORtw \\
\hline
\end{tabular}

Table 4 presents the results of logistic regression 1 with the statement "I am enrolled for my first choice qualification at DUT" as the dependent binary variable where 0 indicates disagreement with this statement and $1=$ agreement. Using the enter method a significant model emerged with both the model chi-square $(\mathrm{p}=0.000<0.001$, $\mathrm{df}=56)$ and Hosmer and Lemeshow's Goodness of Fit $(\mathrm{p}=0.309>0.05, \mathrm{df}=8)$ indicating that its estimates fit the data at an acceptable level. The model's classification table confirms that it accurately predicted the attitudes of $86 \%$ of respondents with respect to the dependent variable. 
Table 4: Model 1- Variables in the Equation

\begin{tabular}{|c|c|c|c|c|c|c|}
\hline & B & S.E. & Wald & df & Sig. & $\operatorname{Exp}(B)$ \\
\hline numchoice & & & 22.837 & 4 & $* * * .000$ & \\
\hline numchoice(1) & 1.681 & 1.090 & 2.378 & 1 & .123 & 5.372 \\
\hline numchoice(2) & -.898 & 1.132 & .630 & 1 & .427 & .407 \\
\hline numchoice(3) & -.546 & 1.233 & .196 & 1 & .658 & .579 \\
\hline numchoice(4) & 19.150 & 37810.366 & .000 & 1 & 1.000 & 207452935.958 \\
\hline studyfield & & & 16.244 & 8 & $* 039$ & \\
\hline studyfield(1) & -2.605 & 1.563 & 2.778 & 1 & .096 & .074 \\
\hline studyfield(2) & -2.917 & 1.549 & 3.548 & 1 & .060 & .054 \\
\hline studyfield(3) & -.689 & 1.611 & .183 & 1 & .669 & .502 \\
\hline studyfield(4) & -1.003 & 1.600 & .392 & 1 & .531 & .367 \\
\hline studyfield(5) & -2.440 & 1.564 & 2.434 & 1 & .119 & .087 \\
\hline studyfield(6) & .642 & 1.615 & .158 & 1 & .691 & 1.901 \\
\hline studyfield(7) & -.949 & 1.500 & .400 & 1 & .527 & .387 \\
\hline studyfield(8) & .346 & 1.840 & .035 & 1 & .851 & 1.413 \\
\hline gebiedsdummy & -1.346 & .602 & 4.999 & 1 & $* .025$ & .260 \\
\hline ERoRtw & -5.713 & 2.545 & 5.039 & 1 & $* .025$ & .003 \\
\hline maed & & & 6.665 & 5 & .247 & \\
\hline $\operatorname{maed}(1)$ & -2.540 & 1.386 & 3.358 & 1 & .067 & .079 \\
\hline $\operatorname{maed}(2)$ & -1.720 & 1.270 & 1.835 & 1 & .176 & .179 \\
\hline $\operatorname{maed}(3)$ & -1.451 & 1.147 & 1.600 & 1 & .206 & .234 \\
\hline $\operatorname{maed}(4)$ & -2.353 & 1.144 & 4.231 & 1 & $* .040$ & .095 \\
\hline $\operatorname{maed}(5)$ & -.451 & 1.060 & .181 & 1 & .670 & .637 \\
\hline paemp & & & 16.638 & 7 & $* 020$ & \\
\hline paemp(1) & -1.155 & .946 & 1.490 & 1 & .222 & .315 \\
\hline $\operatorname{paemp}(2)$ & -1.465 & .962 & 2.321 & 1 & .128 & .231 \\
\hline paemp(3) & .700 & .910 & .592 & 1 & .442 & 2.013 \\
\hline paemp(4) & .750 & 1.111 & .456 & 1 & .500 & 2.117 \\
\hline $\operatorname{paemp}(5)$ & 4.186 & 2.153 & 3.779 & 1 & .052 & 65.764 \\
\hline paemp (6) & -1.410 & .843 & 2.798 & 1 & .094 & .244 \\
\hline paemp (7) & .972 & 1.639 & .351 & 1 & .553 & 2.642 \\
\hline Component2 & -.628 & .293 & 4.612 & 1 & $* .032$ & .534 \\
\hline Component10 & .556 & .211 & 6.970 & 1 & $* * .008$ & 1.744 \\
\hline Constant & 45.965 & 33190.914 & .000 & 1 & .999 & 91738790001315600000.000 \\
\hline
\end{tabular}

a Variable(s) entered on step 1: Compindex, numchoice, studyfield, gebiedsdummy, genderdummy, ERoRtw, paed, maed, paemp, maemp, Component1, Component2, Component3, Component4, Component5, Component6, Component7, Component8, Component9, Component10, Component11, emprospect.

Significant independent variables in Model 1 are: respondents' ranking of DUT as choice of institution to study at (numchoice), study field, expected rate of return (ERORtw), rural versus urban area of residence (Gebiedsdummy), paternal employment status (Paemp) and components C2 and C10. The logistic coefficients (B) are interpreted as the change in the logarithmic odds of the dependent variable associated with a one unit change in the independent variable. Hence a one unit increase in expected rate of return, for instance, decreases the log odds of respondents agreeing with the statement "I am enrolled for my first choice qualification at DUT" by a factor of 5.713. The corollary of this is that the smaller the expected rate of return, the more respondents are likely to agree with the statement. This implies that respondents associate better returns either with alternative study fields or institutions, that is, not DUT Pietermaritzburg or universities of technology in general.

Respondents' ranking of DUT as a choice of tertiary institution is, overall, a significant determinant of whether or not respondents agree that they are enrolled at the institution in their first choice programme. The Beta coefficient signs of its multiple dummy categories suggest that respondents who ranked DUT as a first-choice institution were more likely to agree with the statement. Those who ranked DUT as a second or third choice tended to disagree with it. For the most part, study field is also significant with respondents from all study fields, excluding tourism and engineering studies, likely to disagree with the statement. Parental education status, on the whole, is not 
significant although the category of respondents whose mothers have a matric qualification are unlikely to agree that they are enrolled for their first choice qualification at DUT. Paternal employment status, overall, is significant with respondents' whose fathers are employed in the public/semi-public sectors likely to disagree that they are enrolled for the their first choice qualification at DUT and those whose fathers are employed in the private sector or self employed likely to agree with the statement.

\section{Logistic Regression Analysis - Model 2}

It was essential to consider other potential influences on respondents' attitudes toward higher education. To this end, the existing Model 1 dependent variable statement was replaced with the statement: "In my opinion the economic benefits are the most important benefits of higher education" with $0=$ disagreement and $1=$ agreement. The same independent variables were retained bar paternal education level (Paed) and expected employment prospects (Emprospect) which variables had the least significant impact in the previous model. The enter method produced a significant model (model chi square $p=0.032<0.05$ and Hosmer and Lemeshow test $p=0.317>0.05$ ) which correctly predicted $77.7 \%$ of responses to the new dependent variable statement.

Table 5: Model 2- Variables in the Equation

\begin{tabular}{|c|c|c|c|c|c|c|}
\hline & $\mathbf{B}$ & S.E. & Wald & df & Sig. & $\operatorname{Exp}(B)$ \\
\hline maemp & & & 8.702 & 7 & .275 & \\
\hline $\operatorname{maemp}(1)$ & .635 & .884 & .515 & 1 & .473 & 1.886 \\
\hline $\operatorname{maemp}(2)$ & -.477 & 1.193 & .160 & 1 & .689 & .621 \\
\hline $\operatorname{maemp}(3)$ & .990 & .826 & 1.434 & 1 & .231 & 2.691 \\
\hline maemp(4) & .422 & .904 & .217 & 1 & .641 & 1.525 \\
\hline $\operatorname{maemp}(5)$ & 1.704 & 1.455 & 1.372 & 1 & .241 & 5.498 \\
\hline $\operatorname{maemp}(6)$ & 1.456 & .807 & 3.259 & 1 & .071 & 4.290 \\
\hline $\operatorname{maemp}(7)$ & 1.743 & .840 & 4.306 & 1 & $* .038$ & 5.712 \\
\hline ERoRtw & -4.313 & 1.965 & 4.818 & 1 & $* .028$ & .013 \\
\hline Component1 & 1.558 & .436 & 12.756 & 1 & $* * * .000$ & 4.749 \\
\hline Component2 & -.107 & .246 & .191 & 1 & .662 & .898 \\
\hline Component3 & -.280 & .201 & 1.935 & 1 & .164 & .756 \\
\hline Component4 & .004 & .177 & .001 & 1 & .981 & 1.004 \\
\hline Component5 & .195 & .216 & .818 & 1 & .366 & 1.215 \\
\hline Component6 & .437 & .151 & 8.348 & 1 & $* * .004$ & 1.548 \\
\hline Component7 & -.330 & .262 & 1.586 & 1 & .208 & .719 \\
\hline Component8 & .178 & .232 & .590 & 1 & .442 & 1.195 \\
\hline Component9 & 1.028 & .479 & 4.609 & 1 & $* .032$ & 2.797 \\
\hline Component10 & .233 & .173 & 1.823 & 1 & .177 & 1.263 \\
\hline Component11 & .400 & .254 & 2.485 & 1 & .115 & 1.492 \\
\hline Constant & -24.021 & 37810.490 & .000 & 1 & .999 & .000 \\
\hline
\end{tabular}

$* \mathrm{p}<0.05, * * \mathrm{p}<0.01, * * * \mathrm{p}<0.001$

a Variable(s) entered on step 1: Compindex, numchoice, studyfield, maed, paemp, maemp, ERoRtw, Component1, Component2, Component3, Component4, Component5, Component6, Component7, Component8, Component9, Component10, Component11, gebiedsdummy, genderdummy.

Expected rate of return is again significant with a one unit increase in expected rate of return decreasing the $\log$ odds of respondents agreeing with the statement "In my opinion the economic benefits are the most important benefits of higher education" by a factor of 4.313. This result implies that respondents have a wider, not necessarily only economic, appreciation of the value of higher education. However, component $\mathrm{C} 1$, indicated as highly significant, is directly related to agreement/disagreement with the statement which suggests that the higher the general value respondents place on higher education, the more likely they are to agree that the most significant benefits of higher education are indeed economic. That component 9 is directly related to agreement or disagreement with the statement indicates that respondents generally treat the higher education transaction as an investment. Consequently, the higher the present sacrifices they feel they are making, the more likely they are to agree that that the economic benefits are the most significant rewards of a higher education qualification. Component C6 is 
positively and significantly associated with respondents' agreement/disagreement with the statement suggesting that the greater the level of parental guidance respondents received with respect to their study and career plans, the greater respondents' appreciation of the economic benefits of higher education. Respondents' maternal employment status was, overall, not a significant factor.

\section{CONCLUSION}

This paper, within a qualitative research design, and using a limited analysis of respondents' higher education demand, sought to establish whether individuals' expected returns to higher education investments are significantly associated with their enrolment choices. It argued that individual choice can be understood only on the uncertain and normative ground of human expectations, perceptions and beliefs. Such terrain is not suited to neoclassical economic analysis, so traditional human capital theory relies on improbable assumptions about human behaviour to model educational choice. It was suggested that it is not necessary to employ a neoclassical analytical framework to demonstrate that individuals' enrolment decisions may be sensitive to their anticipated returns to higher education investments. In the qualitative tradition, individuals' unqualified beliefs and reasons are taken to inform their actions. This knowledge is sufficient to understand their actions without judging the basis of their choices. However, the general finding that individuals' earnings expectations are mostly market related suggests that they act with the best rationality they can muster in contemplating the higher education decision. It also confirms the potential validity and reliability of qualitative data.

The results of the two logistic regression models employed in this study, using qualitative data, generally support the literature's broad categorization of the determinants of higher education demand. Expected rate of return/employment prospects (economic), perceptions/expectations of higher education (psychological/individual and structural/institutional) and social/familial factors were identified as significant determinants of respondents' attitudes toward aspects of higher education. Specifically, it appears that respondents recognize that higher education entails significant direct and indirect costs yet are prepared to incur the necessary sacrifice and risk in pursuit of this commodity. Expected returns to higher education investments were shown to feature prominently in respondents' thought processes. In spite of this, respondents don't necessarily agree that economic benefits constitute the primary advantage of higher education. Parental guidance, in respect of study and career plans was shown to be instrumental in promoting respondents' economic expectations of higher education.

Paternal employment status (possibly a proxy for family income) was also implicated, although uncertainly, in enrolment choice. Respondents whose homes are in rural areas appear to be more likely than their urban based colleagues to be dissatisfied with their enrolment choices at DUT Pietermaritzburg. This may reflect relatively greater expectations of higher education or simply a desire to be studying in a bigger and more exciting urban centre than Pietermaritzburg. There is some indication that respondents perceive greater labour market advantages in favor of traditional universities relative to universities of technology. Possibly reflective of a quirk of human nature, respondents who perceive the cost of higher education to be high are more likely to be satisfied that they are enrolled for their first choice qualification at DUT while those who consider that it is too low, feel that they might have had better choices. This phenomenon may hint at respondents' possible association of cost with quality; that is, higher cost equates with better quality. These factors, together, betray something of the nature of respondents' higher expectations and can be expected to influence the demand for DUT programmes in the KZN Midlands.

An especially significant finding, however, is that this case study of DUT first year students' enrolment choices 's affirms the human capital theory proposition that individuals regard higher education as an investment; that is, as a risk versus return prospect. Their anticipated private rates of return were shown to be a significant consideration in respondents' thought processes in respect of their higher education choices. This knowledge, however, does not necessarily validate the implicit assumption of national and local higher education policy that the value of schooling is essentially explained by human capital theory.

The single case study approach and purposive sample survey design of this research project raises the issue of representativeness. It could be validly argued that a single case is not representative of the population of DUT students. However, aside from any typicality, no claim is made that the results of the study are valid beyond the case of DUT (Pmb). Interpretive research, such as has guided this analysis, generally does not draw large or random 
samples. What is sampled in qualitative research is determined by the unit of analysis which, in this study, was the single case of DUT (Pmb) chosen for its typicality of the DUT specifically and other South African Universities of Technology generally. Within the case of DUT (Pmb), every reasonable effort was expended to ensure that the sample was representative of the target population. Results were also corroborated with those reported in the literature.

If human capital theory is to be validated as a model of educational choice, future research should strive to present evidence, not only that higher education is considered an investment transaction, but that such education increases individuals' marginal product. Only then can human capital theory be held out as a plausible (and at least partial) explanation of the private demand for higher education.

\section{AUTHOR INFORMATION}

Alex van der Merwe is senior lecturer in economics at the Riverside Campus of the Durban University of Technology, South Africa.

\section{REFERENCES}

1. Boateng, K. and Ofori-Sarpong, E. (2002) An Analytical Study Of The Labour Market For and Social Development Imperatives of South Africa in the $21^{\text {st }}$ Century. Pretoria, CHE.

2. Department of Education. (1997) Education White Paper 3 - A Programme For the Transformation of Higher Education. Notice 1196 of 1997. Pretoria, Government Printer.

3. Blaug, M. (1976) The Empirical Status of Human Capital Theory: A Slightly Jaundiced Survey. Journal of Economic Literature, 14(3), p. 827-855.

4. Cosser, M. and du Toit, J. (2002) From School to higher education? Factors affecting the choice of Grade 12 Learners. Cape Town, HSRC Press.

5. Council on Higher Education. (2000). Towards a New Higher Education Landscape: Meeting the Equity, Quality and Social Development Imperatives of South Africa in the $21^{\text {st }}$ Century. Pretoria, CHE.

6. Dominitz, J. and Manski, C.F. (1996) Eliciting student expectations of the returns to schooling. The Journal of Human Resources, 31 (1), p.1-26.

7. Fields, G.S. (1974) The Private Demand for Education in Relation to Labour Market Conditions in LessDeveloped Countries. The Economic Journal, 84 (336), p. 906-925.

8. Handa, M.L. and Skolnik, M.L. (1975) Unemployment, Expected Returns, And The Demand For University Education In Ontario: Some Empirical Results. Higher Education, vol. 4, p.27-43.

9. Hsing, Y. and Chang, H.S. (1996) Testing Increasing Sensitivity of Enrolment at Private Institutions to Tuition and Other Costs. American Economist, 40 (1), p.40-45.

10. Hung, F., Chung, Y. and Ho, E.S. (2000) To work or to continue to higher education? The choice of senior secondary students in Shenzen, China. Higher Education, 39, p.455-467.

11. Kraak, A. (2006) "Academic drift" in South African universities of technology: Beneficial or detrimental? Perspectives in Education, 24 (3), p. 135-152.

12. Kruss, G. (2002) More, better, different? Understanding private higher education in South Africa. Perspectives in Education, 20(4), p. 15-27.

13. Li, W. and Min, W. (2001) Tuition, Private Demand And Higher Education In China. Discussion paper, Graduate School of Education, Peking University, Beijing, 100871.

14. Menon, M.E. (1997) Perceived Rates of Return to higher Education in Cyprus. Economics of Education Review, 16 (4), p.425-430.

15. Menon, M.E. (1998) Factors influencing the demand for higher education: The case of Cyprus. Higher Education, vol. 35, p.251-266.

16. Michael, C. (1999) Rising Tuition Fees: Measuring the Impact upon Undergraduate Enrolment in Ontario, 1977/78-1996/97. Paper presented to the Canadian Institutional Research and Planning Association, Quebec City, PQ. October 24-26, 1999.

17. Ministry of Education. (1997) Education White Paper 3: A Programme For The Transformation Of Higher Education. Pretoria.

18. Mora, J.G. (1997) Equity in Spanish higher education. Higher Education, Vol. 33, p.233-249. 
19. Mseleku, T. (2001) The National Plan for Higher Education. Paper presented at the $6^{\text {th }}$ Round Table Discussion: The State of Education in South Africa. Discussion series hosted by the National Economic Development And Labour Council (NEDLAC). Auckland Park, 24 April 2001.

20. Mueller, R.E. and Rockerbie, D.W. (2004) Issues in Education Demand: The Ontario Experience. Discussion paper prepared for Higher Education In Canada, John Deutsch Institute for the Study of Economic Policy, Queen's University and Graduate School of Education, Peking University, Beijing, 100871. February 13-14, 2004.

21. Pandor, N. (2005a) Address by the Minister of education, Mrs Naledi Pandor, MP, at the national consultative conference in education. ICC, Durban. 13 May 2005.

22. Pandor, N. (2005b) Address by the Minister of education, Mrs Naledi Pandor, MP, at the national consultative conference in education. ICC, Durban. 31 May 2005.

23. Psacharopolous, G and Sanyal, B. (1982) Student Expectations And Graduate Market Performance In Egypt. Higher Education, Vol. 11, p.27-49.

24. Shim, K.R. (1990) A Simple Demand Function For Higher Education. Atlantic Economic Journal, 18 (4), p.79.

25. Smith, H.L. and Powell, B. (1990) Great Expectations: Variations in Income Expectations Among College Seniors. Sociology of Education, 63 (3), p.194-207.

26. Van der Merwe, A.D. (2008) Determinants of earnings expectations of typical South African University of Technology students. Unpublished paper, Durban University of Technology, Pietermaritzburg, South Africa.

27. Weisbrod, A. (1962) Education and Investment in Human Capital. Journal of Political Economy, 70 (5), p.106-123.

28. Williams, G. and Gordon, A. (1981) Perceived Earnings Functions And Ex Ante Rates Of Return To Post Compulsory Education In England. Higher Education, vol. 10, p. 199-227. 
NOTES 